\title{
ISLAM DAN PERGESERAN BENTUK KERJA PEREMPUAN (STUDIKASUS BURUH BANGUNAN DIKABUPATEN BONE) Islam and Shift of Working form of Women (Case Study of the Construction Worker in Bone Regency)
}

\author{
Oleh: Kurniati Abidin* \\ *Dosen Jurusan Syariah STAIN Watampone \\ Jl. Salak Lr. Latonra No. 4 Watampone \\ E-mail: Kurniati.sbidin@vahoo.co.id
}

\begin{abstract}
Abstrak
Penelitian ini merupakan penelitian kualitatif deskriptif yang bertujuan untuk menggambarkan faktorfaktor yang melatarbelakangi perubahan pekerjaan dari tugas dan kegiatan domestik menjadi pekerja buruh bangunan dan membagijenispekerjaan berdasarkan gender. Informan dalam penelitian ini adalah lima orang tenaga kerja bangunan. Data dikumpulkan melalui wawancara mendalam dan observasi. Hasilpenelitian menunjukkan bahwa faktor ekonomi, pendidikan rendah, dan penemukan teknologi baru untuk bekerja di sawah merupakani faktor menyebabkan seorang wanita beralih ke bekerja sebagai buruh bangunan. Dalam evaluasi dari pembagian kerja, tidak ditemukan adanya pembedaan pekerjaan pekerja buruh bangunan berdasarkan gender.
\end{abstract}

Kata Kunci: pergeseran, Bentuk Kerja Perempuan

\section{Abstract}

This research represent the qualitative research descriptive which aim to depict the factors background in which woman change over thejobfrom domestic activity become the worker of building labour and devide their division oflabor pursuant to gender. Informan in this research arefive people of construction worker. Data collected through circumstantial interview and observation. Result of research indicate that the economic factor, low education, andfinding of new technology to work in the rice field represent the factor of woman cause change over to work as construction worker. In evaluation from division of work, it was not found the existence of segregation ofjob of worker of construction worker pursuant to gender.

Key Words: shift, work andfemale forms.

\section{PENDAHULUAN}

$\mathrm{S}$ alah satu isu penting yang muncul menjelang berakhirnya abad ke 20 adalah persoalan gen der. Isu tentang gender ini telah menjadi bahasan yang memasuki setiap analisis sosial, menjadi pokok bahasan dalam wacana perdebatan mengenai perubahan sosial dan menjadi topik utama dalam perbincangan mengenai pembangunan dan perubahan sosial. Berbagai protes dan gugatan yang terkait dengan gender adalah adanya ketidakadilan dan diskriminasi terhadap kaum perempuan.'

Sejarah dan budaya menganggap kedudukan perempuan selalu menerima kenyataan subordinasi laki-laki. Pembagian kerja secara tegas antara lakilaki dan perempuan berlaku terutama pada lingkungan budaya dimana laki-laki harus bertanggung jawab mencari nafkah dengan menggunakan kekuatan fisik, sedangkan perempuan tinggal di rumah untuk melahirkan, mengasuh, dan merawat anggota keluarganya. Urusan-urusan produktif seakan-akan menjadi tugas laki-laki dan urusan reproduktif (kerumahtanggaan) adalah tugas perempuan. Idealnya perempuan hanya bisa dinilai secara terhormat jika sanggup menjalankan fungsinya tersebut. ${ }^{2}$ Walaupun hal ini tidak mewakili sebuah kebenaran, tetapi konsep ini dipercayai validitasnya dan diwariskan secara turun temurun melalui sebuah proses pewarisan nilai-nilai atau sosialisasi.

Melihat kondisi ini kaum feminisme melakukan penyadaran peran dan fungsi manusia, baik laki-laki maupun perempuan karena feminisme menganggap

Jwi Narwoko dan Bagong Suyanto. 2004. Sosiologi Teks Pengantar dan Terapan. Jakarta: Kencana. h.313.

A.Nurfitri Balasong dan Hasmavvati Hamid. 2006. Perempuan Untuk Perempuan Sketsa Pemikiran Perempuan untuk Pemberdayaan Potensi Perempuan di Sulawesi Selatan. Sulawesi Selatan: Accae Publishing bekerjasama Tim penggerak PKK Propinsi Sulawesi Selatan, 2006 h.xxiv.

$H g$

Jurnal "Al-Qalam" Volume 17 Nomor 1 Januari - Juni 2011

Koreksi naskah I tanggal 16 Maret 2011. Koreksi naskah II tanggal 12 April 2011. Finalisasi Naskah 20 Juni 2011 
:elah terjadi banyak ketimpangan yang dihadapi masyarakat dalam mengaplikasikan kedua hal tersebut. Penyadaran peran adalah laki-laki dan perempuan Kcara kodrati memiliki peran dan fungsi yang berbeda agar keduanya saling mengisi. Peran-peran kodrati tersebut sangat penting karena menyangkut kelang>ungan generasi manusia. Adapun penyadaran fungsi, ?ahwa laki-laki dan perempuan secara fungsional memiliki posisi yang sama di dunia sebagai pengatur vehidupan dunia. Feminisme melakukan penyadaran - arena melihat kenyataan bahwa kedudukan sebagai $\mathrm{r}^{\wedge}$ mimpin banyak didominasi oleh laki-laki, padahal - arusnya perempuan juga memiliki kedudukan yang sama. ${ }^{3}$

Sehubungan dengan hal tersebut Megawangi r elihat bahwa secara de jure, tidak ada hambatan ${ }^{\wedge}$ ruktural bagi perempuan untuk menjadi setara dengan aki-laki, termasuk yang menyangkut faktor keragaman $\wedge$ iologis. Sedangkan secara de facto, banyak peempuan yang secara sukarela tidak dapat melepaskan iktor biologisnya terutama yang berkaitan dengan aspek reproduksi. ${ }^{*}$

Oleh karena itu, Istilah diskriminasi adalah tidak epat karena hambatan yang ada bagi perempuan untuk . tara dengan laki-laki sering datang dari dalam diri rempuan sendiri. Walaupun dapat saja dikatakan rena faktor budaya yang merupakan faktor dari luar i perempuan, dimana konsep gender adalah sosialisasi iaya. Namun faktor budaya tidak lepas kaitannya :gan faktor keragaman biologis, karena di seluruh lia ada keseragaman budaya tentang konsep >.eibuan" yang selalu melekat pada perempuan.

Seiring dengan laju perkembangan dan tuntutan zaman, kondisi saat ini semakin menunjukkan adanya erubahan yang berimplikasi mendorong kemajuan :ran perempuan di semua bidang. Perempuan sudah Mh terbuka menafsirkan nilai-nilai budaya, mereka :ara kuantitas dan kualitas tidak hanya terlibat di nah domestik, tetapi juga aktif di ranah publik. ambaran idealnya kaum perempuan mulai bergesar ilam dunia kerja, yang tadinya merupakan sosok fcbagai ibu rumah tangga yang diidealkan dalam asyarakat, kemudian bergesar ke dalam suatu peran igjauh lebih kompleks di luar rumah tangga. Mereka :ulai mencari kerja untuk membantu ekonomi jluarganya.
Perempuan sebagai salah satu sumber daya manusia dalam pencari nafkah dewasa ini semakin tinggi, hal ini dapat di lihat dari semakin tingginya partisipasi perempuan dalam mencari pekerjaan seperti terlihat pada tabel 1 dibawah ini:

Tabel. 1

Banyaknya Pencari Kerja Menurut Kecamatan dan Jenis Kelamin di Kabupaten Bone Tahun 2006

\begin{tabular}{|c|c|c|c|c|}
\hline No & KECAMATAN & LAKI-LAKI & PEREMPUAN & JUMLAH \\
\hline 1 & Bontocani & 21 & 40 & 61 \\
\hline 2 & Kahu & 54 & 126 & 180 \\
\hline 3 & Kajuara & 41 & 75 & 116 \\
\hline 4 & Salomekkko & 16 & 28 & 44 \\
\hline 5 & Tonra & 41 & 25 & 66 \\
\hline 6 & Patimpeng & 27 & 46 & 73 \\
\hline 7 & Libureng & 38 & 41 & 79 \\
\hline 8 & Mare & 41 & 74 & 115 \\
\hline 9 & SibuluE & 76 & & 191 \\
\hline 10 & Cina & 78 & 106 & 184 \\
\hline 11 & Barebbo & 83 & 106 & 189 \\
\hline 12 & Ponre & 46 & 31 & 77 \\
\hline 13 & Lap pari aja & 43 & 57 & 100 \\
\hline 14 & Lamuru & 27 & 48 & 75 \\
\hline 15 & Tellu Limpoe & 19 & 29 & 48 \\
\hline 16 & Bengo & 36 & 48 & 84 \\
\hline 17 & Ulaweng & 61 & 75 & 136 \\
\hline 18 & Palakka & 71 & 95 & 166 \\
\hline 19 & Awangpone & 57 & 62 & 119 \\
\hline 20 & Tellu SiattingE & 44 & 76 & 120 \\
\hline 21 & Amali & 28 & 42 & 70 \\
\hline 22 & Aj an gale & 22 & 45 & 67 \\
\hline 23 & Duo Boccoe & 55 & 65 & 120 \\
\hline 24 & Cenrana & 49 & 72 & 121 \\
\hline 25 & T.Riattang Barat & 306 & 420 & 726 \\
\hline 26 & Tanete Riattang & 449 & 611 & 1060 \\
\hline 27 & T.Riattang Timur & $\wedge 84$ & 377 & 661 \\
\hline & $.11 \mathrm{MI}$ AH & 2113 & 2935 & 5048 \\
\hline
\end{tabular}

Sumber Data: Dinas Tenaga Kerja dan Transmigrasi Kab. Bone

Pada tabel di atas terlihat bahwa dari 27 kecamatan di Kabupaten Bone, penduduk Tanete Riattang dalam hal ini perempuannya merupakan pencari kerja yang terbesar (611 orang) dibandingkan dengan laki-laki (449 orang) dan yang paling terkecil adalah penduduk Kecamatan Tonra yaitu 25 orang perempuan.

Seiring dengan terbukanya kesempatan perempuan dalam dunia kerja, terbentang pula harapan-harapan dan angan-angan yang mungkin akan diraih. Sebagian perempuan akan bercita-cita bekerja di kantor dan meniti karir dan sebagian lagi tidak ingin terikat oleh ruang dan waktu di belakang meja dan sebagian lagi tidak memaksakan diri harus menjadi ini atau itu tetapi lebih tergantung pada situasi yang ada. Mereka inilah yang menurut peneliti adalah pencari kerja yang

Mursyidah Thahir. 2000. Jurnal Pemikiran Islam Tentang Pemberdayaan Perempuan. Jakarta: PP Muslimat, h.75.

Me gavvangi. 1999. Metnbiarkan Berbeda: Sudut Pandang Bant Tentang Relasi Gender. Bandung: Pustaka Mizan, h. 39. 
lebih dari 4 jam sehari, mungkin persoalan ini tidak terlalu merisaukan, tetapi yang terjadi di lapangan di lihat dari banyaknya waktu yang mereka curahkan sebagai buruh bangunan, tidak ada bedanya dengan curahan waktu orang dewasa. Een berkata:

"Sayabekerja mulai jam 8.00 sampai jam 17.00. Jam 12.00-13.00 kami istirahat untuk makan siang. Sesudah makan siang kami bekerja lagi. Kerja saya angkat batu, angkat campuran, buat campuran. Semua pekerja di sini sama jam kerjanya." (Wawancara tanggal 17 Desember 2008)

Hal ini terlihat bahwa di usia sekolah yang sepantasnya mereka harus duduk dibangku sekolah dengan keterpaksaaan harus meninggalkan bangku sekolah. Walaupun pemerintah telah mencanangkan pendidikan gratis, namun pihak orang tua masih harus mengeluarkan uang untuk kebutuhan sekolah anaknya yang lebih banyak bila dibandingkan dengan biaya SPP gratis yang diberikan pemerintah. Seperti membeli buku-buku pelajaran yang tidak tersedia di sekolah, membeli Lembaran Kerja Siswa (LKS), membeli seragam sekolah, yang semua ini sangat memberatkan orang tua bila anaknya sekolah. Akibatnya mereka berhenti sekolah untuk meringankan beban orang tua. Daripada mereka menganggur di rumah, mereka mencoba ikut orang tuanya bekerja menjadi buruh bangunan.

Faktor lain yang menyebabkan perempuan bekerja sebagai buruh bangunan adalah minimnya tingkat pendidikan yang dimiliki oleh informan. Dari kelima informan, empat orang informan cuma tamat SD dan seorang tidak tamat SD.

Latar belakang kondisi ekonomi yang rendah, merupakan alasan mengapa mereka tidak melanjutkan pendidikannya. Daripada mereka menganggur di rumah, mereka mencoba mencari pekerjaan yang sesuai dengan tingkat pendidikannya. Sn (inisial) menuturkan:

Saya cuma tamat SD, saya tidak bisa lanjut sekolah karena terbentur biaya. Kebetulan ada saudara yang mengajak kerja sebagai buruh bangunan, katanya kerjanya tidak dibutuhkan pendidikan tinggi-tinggi karena kerjanya cuma angkat batu, buat campuran dan angkat campuran, makanya saya coba-coba karena untuk mencari pekerjaan dengan pendidikan yang cuma tamat SD, mau kerja apa? Mau jadi pembantu rumah tangga diperlukan kepercayaan." (Wawancara tanggal 17 Desember 2008)
Faktor lain penyebab perempuan beralih bekerja sebagai buruh bangunan adalah adanya teknologi baru dalam pertanian sehingga tenaga yang dibutuhkan untuk mengolah sawah semakin berkurang serta terjadinya pergeseran pola pertanian tradisional ke bentuk-bentuk tanaman pertanian yang intensif. Hal ini diungkapkan Ik:

"Sayajuga bantu bapaknya di sawah, tapi tidak tiap hari, kan udah ada alat canggih atau traktor untuk olah sawah, nanti waktu potong padi (massangki) barulah saya turun ke sawah. Jadi sebelum potong padi saya bekerja sebagai buruh bangunan" (Wawancara tanggal 17 Desember 2008).

Dengan demikian, tampak salah satu penyebab perempunan bekerja sebagai buruh bangunan atau melakukan pekerjaan ganda karena desakan ekonomi keluarga yang tidak mencukupi jika hanya mengandalkan hasil pertanian.

Bila di tinjau dari pembagian kerja, secara sederhana apa yang dikatakan Barron dan Norris tampak pada pekerja buruh bangunan bahwa ada segragasi kerja atas dasar jenis kelamin yang cukup ketat. Caki-laki umumnya menempati jenis-jenis pekerjaan yang lebih stabil, berupah lebih tinggi dan dikategorikan sebagai pekerja terampil, misalnya memasang genteng, memasang tegel, memasang batu bata dan lain-lain. Sebaliknya, perempuan umumnya menempati pekerjaan yang tidak stabil, berupah lebih rendah, mengangkat batu, menggali dan mengangkat air dan lain-lain. Kenyataan tersebut tidak ditemukan dalam penelitian ini. Dari wawancara dengan 5 informan diperoleh bahwa umumnya mereka berpendidikan rendah ditambah tidak mempunyai pengalaman yang banyak (baca: baru bekerja sebagai buruh bangunan) mengakibatkan mereka diberi pekerjaan hanya untuk membuat campuran, mengangkat batu, mengggali, sedangkan buruh yang sudah berpengalaman (baca: tukang batu) mempunyai pekerjaan memasang batu bata, memasang tegel, memasang gentang, yang tentu penghasilan mereka jauh berbeda dengan buruh bangunan. Pekerja buruh bangunan laki-laki maupun perempuan diberi upah yang sama RP. 25.000,- perhari sedangkan tukang batu diberi upah Rp. 35000,- sampai 40.000,-. Hal ini disebabkan pekerjaan mereka jauh lebih sulit dan berat bila dibandingkan dengan buruh bangunan. Iin mengungkapkan:

"Bagi saya tidak ada perbedaaan di antara kami di sini. Kami sebagai buruh bangunan karena tidak 
mempunyai pengalaman kerja, saya saja baru pertama kali bekerja sebagai buruh bangunan. Upah yang diberikan juga sama Rp 25.000,- untuk buruh bangunan baik laki-laki maupun perempuan, kecuali tukang batu mereka mendapat mungkin bisa Rp 40.000,- perhari karena pekerjaan mereka jauh lebih susah dan berat daripada kami."

Dalam konteks tersebut, dilihat dari perspektif ajaran Islam bahwa pergeseran kerja perempuan menjadi buruh bangunan, pada dasarnya tidak terdapat masalah sepanj ang perempuan tidak mendapatkan perlakuan yang bersifat diskriminatif. Islam sejak awal ditargetkan sebagai agama pembebasan, terutama pembebasan terhadap kaum perempuan. Bisadibayangkan, bagaimanamasyarakat Arab yang misoginis dan dikenal sering membunuh anak perempuan, tiba-tiba diperintah melakukan pesta syukuran $\boldsymbol{i}$ aqiqah) atas kelahiran anak perempuan, meski baru sebatas seekor kambing untuk anak perempuan dan dua ekor bagi anak laki-laki. Bagaimana suatu masyarakat yang tidak mengenal konsep ahli waris dan saksi perempuan, tiba-tiba kepada perempuan diberi hak waris dan hak persaksian, meski baru dalam batas satu berbanding dua untuk anak laki-laki. Perempuan yang mati terbunuh, tibatiba harus juga mendapatkan bagian dari denda (diyat), meski masih sebatas seperdua dari yang diperoleh laki-laki.

Di samping itu, keterlibatan perempuan menjadi buruh bangunan tidak perlu dipertentangkan dengan Islam karena perempuan dan laki-laki mempunyai hak yang sama untuk mencari nafkah. Kesetaraan antara laki-laki dan perempuan dalam arti persamaan untuk mendapatkan r.ak-haknya serta melakukan pekerjaan, tercermin pada OS. al-Ahzab:35 sebagai berikut:

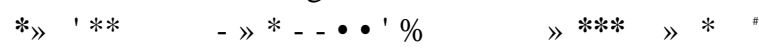

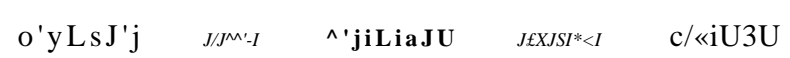

Terjemahnya:

Sesungguhnya laki-laki dan perempuan yang muslim, laki-laki dan perempuan yang mukmin, lakilaki dan perempuan yang tetap dalam ketaatannya, '.iki-laki dan perempuan yang benar, laki-laki dan perempuan yang sabar, laki-laki dan perempuan yang khusyuk, laki-laki dan perempuan yang bersedekah, laki-laki dan perempuan yang berpuasa, laki-laki dan perempuan yang memelihara kehormatannya, laki-laki dan perempuan yang banyak menyebut (nama) Allah, Allah telah menyediakan untuk mereka ampunan dan pahala yang besar. ${ }^{6}$

Jika ayat tersebut diletakkan dan dilihat pada konteks yang tepat, jelaslah bahwa agama Islam tidak membedakan antara kaum muslim dan muslimah. Perempuan harus beriman dan laki-laki demikian juga, mereka memperoleh status yang setara. Bahkan ditegaskan bahwa perempuan mempunyai hak untuk mencari nafkah. Bagi laki-laki memperoleh keuntungan dari apa yang mereka perbuat dan untuk perempuan memperoleh keuntungan dari apa yang mereka perbuat. Ketidak-adilan berasal dari struktur sosial yang menyebabkan superioritas laki-laki atas perempuan.

Islam sangat memberi perhatian yang besar terhadap kaum perempuan dengan menempatkannya pada posisi yang mulia, sehingga tidak sedikit nashnash al-Qur'an yang memberikan dukungan dan kedudukan terhadap diri kaum perempuan. Menurut 'Ukkasyah Abdul Mannan al-Thayyibi bahwa, Islam sangat memperhatikan kaum perempuan dari dua segi, yaitu: pertama, segi kemanusiaan. Dari segi kemanusiaan perempuan sejak dahulu terabaikan dan hanya dijadikan alat untuk memberikan kenikmatan atau digambarkan dalam bentuk iblis yang menjijikkan dan memuakkan, yang diwaspadai makar dan tipuannya. Oleh karena itu, Islam yang agung memberikan batasan-batasan dan mengatur unsur biologis dengan perkawinan dan menerangkan tata cara berinteraksi dalam rumah tangga dan memformalkannya dengan jumlah metode dasar interaksi dalam rumah tangga dan hubungan kekeluargaan.

Kedua, hak sosial. Sebelum Islam, perempuan tidak ada hak untuk mengutarakan pendapatnya, atau ikut serta dalam sebuah tanggung jawab. Mereka dilarang berperan dalam hal-hal tersebut karena keegoisan lakilaki, kebodohan dan otoriternya dalam setiap hak. Oleh karena itu, Islam menolak semua kekeliruan itu bahkan memberikan yangterbaik kepada perempuan. Bahkan, Islam meletakkan perempuan dalam konteks kemanusiaan, sosial kebebasan, dan keagamaan.

\footnotetext{
‘ Tim Penyusun RI. 1996. Al-Qur'an dan Terjemahnya, Jakarta: Departemen Agama Rl, h. 673

' al-Thayyibi, 'Ukkasyah Abdul Mannan. 2002 Asyifat al-Mathlubah Fi al-Binth Waassaujah diterjemahkan oleh Alimin dan H. Fauzun Jamal dengan judul Etika Muslimah: Bimbingan Praklis dari Serambi Rasulullah saw, Jakarta: Cendekia.
} 
Kaitannya dengan hak perempuan untuk bekerja, Islam memandang bahwa pekerjaan apapun boleh dilakukan oleh seorang perempuan sepanjang tidak menimbulkan bencana pada diri, keluarga dan orang lain. Dalam hal ini, bekerja untuk merfcari nafkah dibolehkan apabila itu yang terbaik bagi dirinya. Jika menjadi kepala negara saja telah dibolehkan apalagi dalam bidang yang lebih ringan tentu, tidak ada masalah, seperti hak bekerja di luar rumah, bagi para perempuan karier. Dikatakan demikian karena prinsip yang sangat mendasar dalam al-Qur'an adalah tidak ada perbedaan hak mendapat pekerjaan bagi laki-laki dan perempuan, tanpa terikat satu tempat baik di dalam rumah maupun diluar rumah hanya prosesnya tentu ada ketentuan penyesuaian dengan status dan kemampuanya. Berfirman:

Dalam QS. al-Nisaa ayat 32. Allah swt.

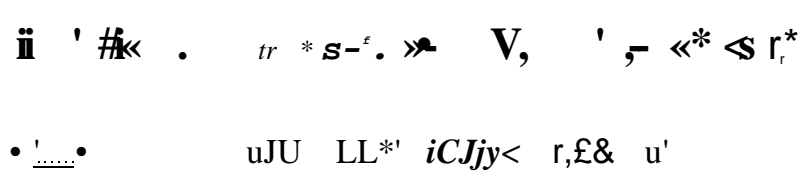

Terjemahan:

Dan janganlah kamu iri hati terhadap apa yang dikaruniakan Allah kepada sebahagian kamu lebih banyak dari sebahagian yang lain. Karena bagi orang laki-laki ada bagian daripada yang mereka usahakan, dan bagi para wanita (pun) ada bagian dari apa yang mereka usahakan dan mohonlah kepada Allah sebagian dari karunia-Nya. Sesungguhnya Allah mengetahui segala sesuatu.

Dalam hak kebebasan bekerja, al-Qur'an mengisahkan tentang dua anak gadis Suaib yang bekerja di luar rumah sebagai gembala ternak milik ayahnya. Dalam hal ini al-Qur'an memberi contoh hak perempuan untuk bekerja di luar rumah asalkan disesuaikan dengan kondisi yang ada. Hal ini berarti bahwa perempuan dapat bekerja mencari nafkah di luar rumah sesuai dengan berprofesinya masing-masing. ${ }^{10}$

Selain itu, Islam memandang bahwa perempuan berhak dalam hukum ekonomi, kewarisan, dan perkawinan, serta peradilan. Al-Qur'an dalam memberikan hak-hak seorang perempuan dalam masalahmasalah yang berkenaan dengan ekonomi bagi setiap kaum perempuan. Dalam hal ini, tidak terdapat larangan dalam Islam bagi perempuan untuk ikut serta memperbaiki ekonominya. Bahkan lebih dari pada itu, Islam memberikan hak bagi setiap perempuan untuk melakukan akad seperti membeli, menjual, melakukan kontrak dan mendapatkan penghasilan serta mengelola uang harta miliknya sendiri.

\section{Kesimpulan}

Faktor ekonomi, pendidikan yang rendah dan ditemukannya teknologi baru untuk mengolah sawah merupakan faktor penyebab perempuan bekerja sebagai buruh bangunan. Di tinjau dari pembagian kerja tidak ditemukan adanya segregasi kerja pada pekerja buruh bangunan berdasarkan jenis kelamin. Sedangkan dari perspektif Islam, pergeseran kerja perempuan menjadi buruh bangunan, tidak mengalami permasalah dengan ajaran agama Islam. Bahkan, mencari nafkah atau bekerja merupakan salah satu perintah Allah, baik kepada lakiilaki maupun perempuan.

\section{Ucapan Terima Kasih}

Ucapanterimakasihdisampaikan kepada pengelola Jumal al-Qalam atas kesediannya memuat tulisan kami. Ucapan yang sama juga disampaikan kepada STAIN Watampone yang telah membiayai penelitian ini serta kepada semua pihak yang telah berpartisipasi dalam penyelesaian penelitian ini. Semoga Allah melimpahkan rahmatnya kepada kita.

\section{DAFTAR PUSTAKA}

Balasong, A.Nurfitri dan Hamid, Hasmawati. 2006. Perempuan Untuk Perempuan Sketsa Pemikiran Perempuan untuk Pemberdayaan Potensi Perempuan di Sulawesi Selatan Sulawesi Selatan: Accae Publishing bekerjasama Tim penggerak PKK Propinsi Sulawesi Selatan.

Megawangi. 1999. Membiarkan Berbeda: Sudut Pandang Baru Tentang Relasi Gender. Bandung: Pustaka Mizan.

Narwoko, J Dwi dan Suyanto, Bagong. 2004. Sosiologi Teks Pengantar dan Terapan. Jakarta: Kencana.

Saftari, Ratna. 1997. Perempuan Kerja dan Perubahan Sosial (Sebuah Pengantar Studi Perempuan.) Jakarta: Pustaka Utama Grafiti.

Thahir, Mursyidah. 2002. Jurnal Pemikiran Islam Tentang Pemberdayaan Perempuan. Jakarta: PP Muslimat.

al-Thayyibi, 'Ukkasyah Abdul Mannan. 2002. Asyifat al-Mathlubah $\mathrm{Fi}$ al-Binth Waassaujah diterjemahkan oleh Alimin dan $\mathbf{H}$. Fauzun Jamal dengan judul Etika Muslimah; Bimbingan Praktis dari Serambi Rasulullah saw, Jakarta: Cendekia.

Zaini, Wahid dkk. 1999. Memposisikan Kodrat: Perempuan dan Perubahan dalam Perspektif Islam, Jakarta: Mizan

\footnotetext{
"Syekh 'Ukkasyah Abdul Mannan atth-Thayyibi. 2002. Asyifat al-Mathlubah Fi al-Binth Waassaujah diterjemahkan oleh Alimin dan H. Fauzun Jamal dengan judul Etika Muslimah; Bimbingan Praktis dari Serambi Rasulullah SAW. Jakarta: Cendekia, h. 20, Lihat juga pada Zakiah Derajat, Islam dan Perananan Wanita, h. 30

, Departemen Agama, RI. op.cit.. QS. An-Nisa: 32

${ }^{10}$ Wahid Zaini dkk. 1999. Memposisikan Kodrat: Perempuan dan Perubahan dalam Perspektif Islam. Jakarta: Mizan, h. 20.
} 